\title{
Politisk framing er politisk magt
}

Jens Jonatan Steen

Analysechef i Tænketanken Cevea

"The immune system, the hypothalamus, the ventro-medial frontal cortices, and the Bill of Rights have the same root cause."

Antonio Damasio, Descates' Error

Når betegnelser som 'statsgældskrise', 'skattelettelse' og 'byrdestop' præger den politiske debat, er det en bestemt ideologisk linje, der sætter den politiske dagsorden. Selvom vi ikke altid er bevidste om det, har disse ord rødder i politiske værdier. Sproget er nemlig ikke neutralt. Det er langt mere end et udtryksmiddel - det er en genvej til hjernen. De ord, vi bruger, påvirker direkte folks opfattelse af og ønsker for samfundet. Fænomenet kaldes framing - og må tages i brug af venstrefløjen i dens politikformulering fremover, hvis den skal tilbagevinde den politiske dagsorden.

\section{Værdier er framingens udgangspunkt}

Implicit argumenterer sproget altid, hvilket betyder, at retorik, og særligt brug af metaforer, kan ændre, hvordan vores hjerne opfatter budskaber og den måde, vi tænker på - ofte helt uden at vi opdager det (Nelson et al., 1997). Af disse grunde er sproget et værdifuldt politisk redskab, hvis man formår at bruge det til sin fordel (Edelman, 1971). Derfor er det også vigtigt, at vi ikke opfatter sproget som neutralt eller afkoblet fra virkeligheden, sådan som mange politikere gør det i dag. Der findes masser af eksempler på sådanne misforståelser i den politiske hverdag, hvilket denne udtalelse fra sundhedsminister Astrid Krag vidner om: „Det er meningsløst at hænge sig så meget i ord. Måske vi bare skulle i gang med at diskutere, hvordan vi kan hjælpe de her mennesker. ${ }^{{ }^{1}}$ Ved at indtage den position vil enhver politiker begå en afgørende fejl ved ikke at erkende, at sproget ofte skaber sin egen virkelighed (Vatz, 1973). Det er vigtigt at forstå betydningen af den framing, som vi omgiver os med i politisk debat (Iyengar, 1991). Hvis man ikke gør det, vil man altid tabe.
Dette er budskabet hos en af hovedtænkerne inden for politisk framing og kognitiv lingvistik, professor George Lakoff, som gennem en årrække har beskrevet både de teoretiske og politiske sider af framing. Lakoffs anvendelse og overførsel af begrebet framing til en moderne partipolitisk kontekst vil danne grundlag for denne analyse af den danske venstrefløjs aktuelle krise.

Framing har som begreb forgrenet sig temmelig bredt og bliver derfor også tillagt flere forskellige faglige betydninger. Uanset hvilken fagtradition begrebet bruges inden for, så hænger framing tæt sammen med erkendelsen af, at det er umuligt at udtrykke sig fuldstændigt objektivt og neutralt, da alle ord bærer en værdimæssig ladning i sig selv (Black, 1970). I en politisk kontekst drejer framing sig om, hvilke grundlæggende idéer og værdier politikernes retorik og metaforbrug afspejler.

Denne artikel vil introducere framing som fænomen, se på, hvilken rolle framing spiller i politik, og anskueliggøre dette gennem en række konkrete eksempler på politisk framing, herunder konflikten på Restaurant Vejlegården. Som eksemplerne vil vise, er framing ikke bare et amerikansk fænomen, men er i den grad også relevant, og allerede i spil, i dansk kontekst. Framing eksisterer altså på tværs af partisystemer, ideologiske retninger og demokratiske traditioner. Endvidere vil artiklen vise, at det danske centrum-venstre har en stor udfordring, når det kommer til at sætte den politiske dagsorden gennem framing.

\section{Metaforer strukturerer vores tankegang}

Vores opfattelse af verden er metaforisk i den forstand, at alle abstrakte begreber forstås gennem metaforer. Grundlæggende metaforer, såsom den universelle forståelse af, at 'op' er mere og 'ned' er mindre eller af 'kolde' og 'varme' 
personer. Dette er eksempler på dybde-frames, ud fra hvilke vi danner vores opfattelse af, hvad der er rigtigt og forkert. Siden George Lakoff og Mark Johnson udgav bogen „Metaphors We Live By“ i 1980, har man gradvist fået større bevidsthed om, hvilken central betydning metaforer og frames har for den menneskelige erfarings- og meningsdannelse.

Gennem kropslige erfaringer indlejres grundlæggende metaforer i os alle. De danner basis for forstålse af mere abstrakte fænomener, herunder også vores politiske overbevisninger (Johnson og Lakoff, 1980). Vi forstår altså verden i billeder og metaforer, frem for objektive fakta (Nelson et al., 1997). Metaforerne fungerer som en slags mentale strukturer, der gør det muligt for mennesket at forstå virkeligheden med alle dens kompleksiteter (Iyengar, 1991). Dette udnytter strategisk framing: Her udnyttes velvalgte metaforer til at aktivere den virkelighedsforståelse, som afsenderen ønsker, at modtager skal have. Framing kan altså anvendes strategisk til at forme virkeligheden, men framingteori kan også anvendes analytisk.

\section{Framingens tre niveauer}

Når framing bruges analytisk, skelner man mellem framingens tre niveauer: Overflade-frames, sagsdefinerende frames og dybde-frames (Lakoff, 2006), sådan som det fremgår af figur 1. Overflade-frames betegner de konkrete ord, som vi bruger om abstrakte fænomener i vores hverdag. Et eksempel kunne være udtrykket 'cafépenge', som er blevet brugt om uddannelsesstøtten til hjemmeboende. Overflade-frames er altså de konkrete ord, hvori en dybde-frame udmøntes i praksis.

\section{Figur 1}

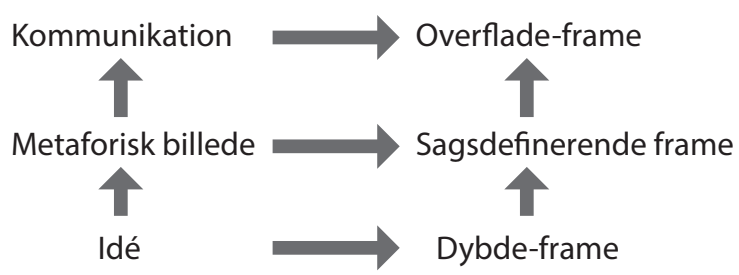

Figuren illustrerer framingens tre niveauer og deres praktiske anvendelse og udmøntning i retorik. Man må starte med at gøre sig sine grundlæggende værdier klart, før man kan kommunikere hensigtsmæssigt.

Sagsdefinerende frames betegner de billeder, som overflade-frames umiddelbart skaber hos modtageren. Med udtrykket 'cafépenge' associerer man f.eks. til unge, der hygger sig med cafe latte på en café - for skatteborgernes penge, som de får for at uddanne sig. De sagsdefinerende frames er dem, der definerer problemet, udpeger problemets årsager og løsningsmulighederne. I en debat er de sagsdefinerende frames altså afgørende for den måde, hvorpå folk taler om og forstår den pågældende sag (Lakoff, 2006).

Dybde-frames tilsiger en bestemt moralsk vurdering af sagen og fælder dermed dom på baggrund af de konkrete udtryk og disses billedskabende effekter. Hvis vi tager eksemplet med cafépengene, så resulterer denne overflade-frame i, at det ikke forekommer retfærdigt, at de unge modtager uddannelsesstøtte: Hvis de alligevel bruger SU-pengene på cafébesøg, når de burde være flittigt bøjet over bøgerne, hvorfor skal vi så belønne dem? Og hvis de har råd til cafe latte, så må SU'en da være alt for høj? Med denne framing kommer diskussionen til at handle om, hvorvidt SU'en er velfortjent. De ord, som vi bruger og hører, aktiverer ikke bare vores grundlæggende værdier og forestillinger - overflade-frames kan rent faktisk forme og forandre disse.

Strategisk framing er en måde at føre politik på, som taler direkte ind i den mentalt ubevidste meningsdannelse, og går forud for specifikke politiske tiltag. Framingen aktiverer dybde-frames og dermed de grundlæggende idéer og værdier. Framing skal ikke blot tages i brug for at retfærdiggøre allerede eksisterende politikker. Al konkret politik bygger nemlig på et ofte ubevidst fundament af moralsk stillingtagen; er det konkrete politiske tiltag rigtigt og retfærdigt? Den måde, hvorpå sagen er blevet framet forud for den politiske beslutningsproces, er således afgørende for, hvilke løsninger der vil forekomme mulige, fornuftige og retfærdige.

\section{Framing er baseret på naturvidenskab: kognition}

Framing er en proces, der direkte påvirker vores hjerner. Hjernen er stadig et stort mysterium, men fra videnskaben ved vi, at når vi opfatter et givet enkeltobjekt, f.eks. en blå kasse, så opfatter vi 'blå' og 'kasse' to forskellige steder i hjernen. Dette sker gennem de bindinger, som opstår i neurale kredsløb i vores hjerner, når vi skal forstå et givent fænomen (Lakoff, 2008a, Bergen, 2012; Landau et al, 2010). Vores individuelle virkelighedsopfattelser styres altså af neurologiske forbindelser, som dagligdagens sprog aktiverer gennem metaforer og frames (Lakoff 2008a).

I kognitionsvidenskaben finder vi endnu et argument for at tale til folks dybtliggende værdier: Ifølge forskeren Michael Gazzinga er langt størstedelen af vores hjerneaktivitet nemlig kognitiv ubevidst, estimeret 95-98 procent, hvilket betyder, at når vi beder menneskehjernen om at forholde sig til logiske og faktuelle politiske argumenter, så taler vi, lidt populært sagt, kun til de få procent af hjernen, som ræsonnerer bevidst (Gazzinga i O'Neill, 2009). Den teknokratiske retoriks tilstræbte objektivitet 
giver derfor bagslag, idet det kognitivt ubevidste spiller en enorm rolle for den enkeltes politiske holdninger og forestillinger om verden (Lakoff 2008a). Venstrefløjen kan derfor med fordel benytte et venstreorienteret sprog, særligt en venstreorienteret framing, der direkte understøtter venstreorienterede værdier, i stedet for at forlade sig på en rationalistisk argumentation.

\section{Moderne politik som en framing-disciplin}

Framing er altså en grundlæggende fysiologisk proces, som altid har påvirket menneskers opfattelse af virkeligheden. Denne erkendelse nåede tilsyneladende højrefløjen langt tidligere end venstrefløjen. Strategisk framing begyndte således at sprede sig $\mathrm{i}$ konservative miljøer $\mathrm{i}$ USA for mere end 30 år siden. En bevidst højreorienteret framing viste sig i de republikanske meningsdanneres retorik allerede tilbage under Ronald Reagans embedsperiode i 1980 'erne og tog fart under George H.W. Bush i starten af 1990'erne (Lakoff 2004). Højrefløjen erkendte dengang, at magten i samfundet ikke alene var vundet ved at vinde magten i Det Hvide Hus, men at det også gjaldt om at vinde folkets "hearts and minds“. Det gjorde man ved at tale politik ud fra egne værdier. Magten blev ikke vundet ved at indtage bestemte positioner, men i rent værdimæssigt at sætte dagsordenen og flytte overbevisninger (Lakoff 2004).

Et af de store navne i dette opgør var den politiske strateg Frank Luntz, der bl.a. har skrevet en framingguide med "The 14 Phrases Never to Use", der indeholder meget konkrete anbefalinger til, hvad man bør og ikke bør sige som republikaner (Luntz, 2006: 165-169). Den centrale pointe hos Luntz er, at republikanerne kan vende den offentlige stemning ved at reframe de politiske sager og helt bogstaveligt tale ud fra egne værdier. I adskillige sager har han fået ret. Med Luntz i spidsen lærte republikanerne at undgå at bruge venstrefløjens sprog og i stedet give udtryk for, og holde fast i, de ærkerepublikanske værdier.

Det betød, at Luntz instruerede republikanerne i konsekvent at bruge bestemte vendinger: I stedet for at tale om at 'balancere de offentlige budgetter', så handlede det nu om at 'stoppe spild af offentlige skattekroner', og i stedet for 'fælles sundhedspleje', talte de om 'retten til selv at vælge'. Disse overflade-frames knytter således direkte an til dybde-frames indeholdende republikanske værdier. De bidrager dermed til at understøtte den kernerepublikanske ambition om en mindre stat og udtrykker modviljen mod statslig sundhedspleje. Republikanerne i USA holder sig meget præcist til et højrefløjssprog, der binder an til stærke sagsdefinerende frames, som formulerer både løsninger og holdninger i forhold til ethvert emne.
Denne strategi har højrefløjen herhjemme og i resten af Europa kopieret og anvendt med stor succes. Samtidig har man fra amerikansk side bevidst forsøgt at sprede de vigtigste politiske frames gennem tænketanke, såsom Cato Institute, Heritage Foundation og Rand Corporation (McGann 2011, Plehwe et al.2006). Kampen for ideologisk framing og eksport af ideer foregår altså meget bevidst på tværs af landegrænser.

\section{Opgør med den 'falske rationalitet'}

Alt imens højrefløjen længe har haft et stramt fokus på at afstemme retorik med værdier, så har det vist sig at være langt sværere for venstrefløjen at forstå sammenhængen. Ifølge Lakoff har venstrefløjen antaget en falsk opfattelse af rationalitet og dermed fuldstændig afgivet den politiskideologiske hjerne til de konservative:

„De progressive (venstrefløjen, red.) har accepteret et forældet billede af rationalitet, der går tilbage til Oplysningstiden, nemlig at rationalitet er bevidst, bogstavelig, logisk, universel, ikke-følelsesladet, ikke-kropsliggjort og tjenende egeninteressen."(Jespersen 2010)

Det betyder, at man hos centrum-venstre har fastholdt den universelle rationalitet og forestillingen om en objektiv sandhed som grundpillen i den politiske tilgang. Man har opfattet sprog som et neutralt formidlingsmiddel, troet, at verden kunne forklares ud fra fakta, grafer og tal, og baseret sin argumentation på disse antagelser.

Den teknokratiske retorik, som dominerer politik i dag, er ikke kun fatal, fordi den tager afsæt $i$, at der eksisterer en objektivt sand og rigtig løsning på politiske problemer - og dermed reducerer politik til holdningsløs embedsførelse (Mouffe, 2005). Den er også fatal, fordi den ikke forholder sig til, hvordan menneskets politiske holdninger aktiveres og dannes $i$ hjernen, og fordi den undervurderer betydningen af, at op mod 98 procent af vores hjerneaktivitet er kognitivt ubevidst (Lakoff, 2008a).

Den kognitive lingvistik udfordrer altså den traditionelle opfattelse af rationalitet og objektivitet. Det, man højest kan opnå, er i bedste fald 'tilstræbt objektivitet'. Det betyder dog ikke, at virkeligheden ikke findes, eller at fakta er en illusion. Det betyder blot, at den tilstræbte objektivitet har sine klare begrænsninger, og at enhver fremstilling vil være påvirket af de dominerende frames. Det er et grundvilkår.

\section{Den indre værdikonflikt}

Mennesker er ikke endimensionelle og abonnerer typisk ikke kun på én enkelt virkelighedsopfattelse, da menneskehjernen er dynamisk og påvirkelig. Dette forhold kan forklares på flere måder, men Lakoff gør det ud fra en belysning af metaforen 'nationen er en familie'. Hans tilgang tager afsæt $\mathrm{i}$ to idealforestillinger om, hvad en 
familie bør være: I 'den patriarkalske familiemodel' er disciplin, selvhjulpenhed og styrke de grundlæggende værdier. Med den patriarkalske familiemodel som ideal vil man derfor finde det naturligt med et samfund præget af hierarki, individualisme og ulighed. I modsætning hertil står 'den omsorgsdragende familiemodel', hvor de grundlæggende værdier er empati og social ansvarlighed. Med denne familiemodel som udgangspunkt bliver lige muligheder og solidaritet mærkesager (Lakoff, 2012). Familiemetaforen giver mere instinktiv mening $i$ en amerikansk optik, hvor diskussionen om idealfamilien er langt mere afgørende, end den er i Danmark i dag. De to familiemodeller kan derfor ses som to yderpositioner, som vi altid kan være påvirkede af, men der findes naturligvis andre familiemodeller med andre værdier og vægtninger i spændet mellem disse, der kan påvirke vores virkelighedsopfattelse.

Lakoff beskriver, hvordan de fleste mennesker vil have versioner af begge familiemodeller indlejret som erfaringer i deres neurale kredsløb. Men ofte vil én familiemodel være den stærkeste og dermed dominere den pågældende persons værdisæt. Langt de fleste mennesker er altså værdimæssigt sammensatte personer - det, Lakoff betegner: „biconceptuals“ (Lakoff, 2008a). Det betyder, at de fleste mennesker vil have nogle forestillinger og holdninger, som er venstreorienterede, og andre, som er højreorienterede (Nelson et al., 1997). Disse tilsyneladende modsigende forestillinger vil altså være til stede samtidig. Den korte naturvidenskabelige forklaring på den forestillingsmæssige dobbelthed er, at i de tilfælde, hvor en person både har en venstreorienteret og en højreorienteret forestilling om en given politik, eksisterer begge forestillinger latent i hjernen. Fænomenet, der kaldes „mutual inhibition" (Lakoff, 2008b, Wunderlich, 2009) eller på dansk 'gensidig blokering', dækker over en situation, hvor to forskellige neurologiske kredsløb i hjernen potentielt set kan aktiveres, men hvor det kredsløb, som rent faktisk aktiveres, samtidig vil blokere for det andet.

Den 'gensidige blokering' står helt centralt i framingteori og har flere implikationer for politisk retorik. Når de neurologiske kredsløb med højreorienterede idéer aktiveres gennem højreorienteret retorik, blokerer de altså samtidig for de venstreorienterede idéer om den pågældende sag. Den gensidige blokering betyder, at de fleste mennesker snildt kan være højreorienterede i nogle henseender og venstreorienterede i andre (Lakoff 2008a). Men fænomenet betyder også, at jo mere konsekvent man aktiverer det højreorienterede tankesæt, des mere blokerer man for det venstreorienterede - og des større er sandsynligheden for, at det højreorienterede tankesæt spreder sig til andre holdningsspørgsmål.
Dertil kommer også det forhold, at frames stadig aktiveres, selvom de i sammenhængen negeres. Når man argumenterer mod en modstanders frame ved eksplicit at nævne denne, bekræfter og styrker man den kun (Lakoff 2004). Man skal i stedet fremføre sin egen overfladeframe og lade denne definere sagen. Den gensidige blokering betyder således, at man som meningsdanner skal gøre sig meget bevidst om, hvilke kredsløb og forestillinger man aktiverer med sine sproglige formuleringer.

Læren om den værdimæssige sammensathed er samtidig også central i forhold til at forklare muligheder og begrænsninger ved at applicere Lakoffs tanker om kognitiv lingvistik og politik. Helt generelt viser forskningen, at grundlæggende metaforer er meget ensartede på tværs af sprog og kulturer (Johnson og Lakoff, 2003), hvorfor den grundlæggende teori udmærket kan overføres til f.eks. danske forhold. Men samtidig er der naturligvis også afgørende forskelle f.eks. i forhold til vores partisystemer. Når Danmark er et flerpartisystem, er der selvsagt flere og mere værdimæssigt sammensatte partier og dermed mulighed for endnu flere frames i det samlede system. Omvendt vil der også altid herske flere grundlæggende værdier, der ikke nødvendigvis umiddelbart harmonerer, i det enkelte parti - uanset om det er et dansk eller et amerikansk et af slagsen. Der vil f.eks. være traditionelle arbejdere hos Socialdemokraterne, som tiltales af den mere 'patriarkalske familiemodel', ligesom der vil være katolske republikanere, der tiltales af 'den omsorgsdragende familiemodel'. Antallet af partier udvisker således hverken muligheder eller behov for at frame de politiske værdier. Et flerpartisystem øger muligvis behovet for klar framing, fordi man har endnu større behov for at skille sig ud og markere sig ideologisk i forhold til de andre partier. Det er således ikke afgørende for den kognitive opfattelse af frames, om det foregår i et politisk system, som er uni-, bi- eller multipolært. ${ }^{2}$ Hjernen vil, som Lakoff påpeger, ofte være forestillingsmæssigt delt, hvilket vil sige, at den, uafhængigt af den eksterne virkelighed og det konkrete politiske system, vil indeholde flere og gerne meget forskellige opfattelser samtidig. Det politiske system vil muligvis påvirke rammerne for, hvordan vi kan påvirkes af forskellige frames, men det kan aldrig udelukke enkelte frames eller stoppe den påvirkning, som framing udsætter os for helt generelt. Framing transcenderer således de politiske højre-venstre-akser i politologien.

\section{Skattesystemet: 'Befriende helte' eller 'onde bebyrdere'}

Begrebet skat har længe været i centrum for den ideologiske framingkamp. Det mest brugte eksempel på framing er derfor også udtrykket 'skattelettelse', som kommer af det amerikanske „tax relief“. Et udtryk, der blev et slags 
Figur 2. Stereotype opfattelser af skat

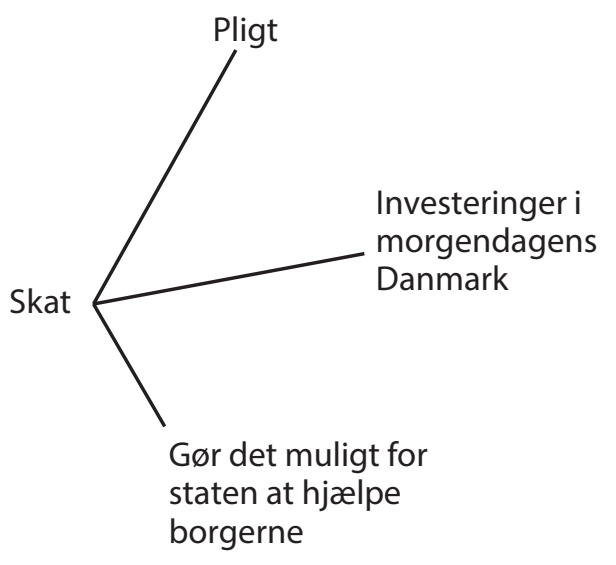

\section{En typisk venstreorienteret opfattelse af skat}

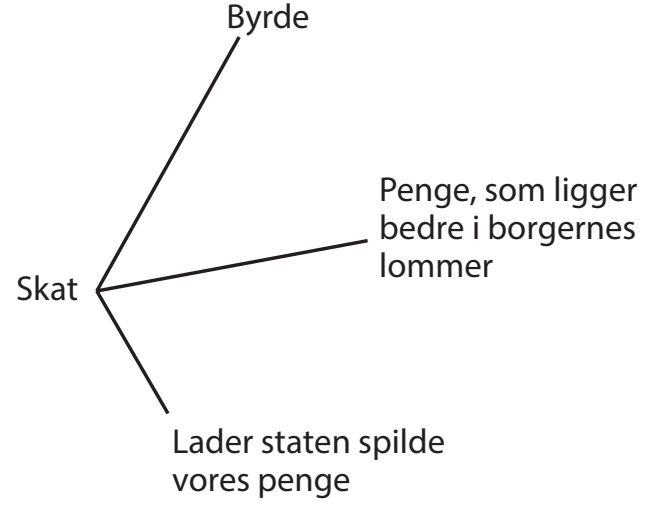

\section{En typisk højreorienteret opfattelse af skat}

Figuren illustrerer, hvordan dybde-framingen af ordet 'skat' har betydning for opfattelsen af fænomenet i den danske offentlighed.

mantra under George W. Bushs præsidentperiode (Lakoff 2004). Ordet virker måske umiddelbart neutralt, men det understøtter i den grad højrefløjens skattepolitiske grundsyn, hvilket illustreres af figur 2. Når det er en lettelse at få sænket skatten, indikeres det, at skat er en slags byrde, som man helst vil være foruden. Samtidig indikerer metaforen, at en person, der er ramt af 'skattebyrden', er et 'offer', og at den, der ønsker at lette eller 'befri offeret' for denne byrde, er en 'helt'. Med overflade-frames som 'skattelettelse' og 'skattetryk' fremstår højrefløjen altså som helte, der vil befri folk fra 'skattebyrden', og modsat fremstår venstrefløjen som de skurke, der vil bevare eller måske ligefrem øge 'byrden'. Et helt aktuelt eksempel på højrefløjens strategiske framing er Lars Løkkes forslag om et 'byrdestop': „Det må ikke gentage sig, at der kommer nye byrder på igen, når regeringen skal lave finanslov med Enhedslisten ",21 udtalte Venstres formand til Politiken og brugte dermed den klassiske højreorienterede dybdeframe helt eksplicit. Med en udtalelse som denne bliver skat ikke en investering eller et bidrag, som man gladelig betaler til fællesskabet og også selv nyder godt af, at andre betaler, sådan som det ville være i venstrefløjens interesse at frame det. Det samme gælder for framen 'skattely', som indikerer, at skat er noget, som man bør forsøge at skærme sig fra og beskytte sig imod. Disse metaforer bygger på klare liberalistiske værdier. Og når disse begreber gentages om og om igen, vil den negative opfattelse af beskatning komme til at dominere i det neurologiske kredsløb i hjernen hos borgerne og dermed aktivere den højreorienterede tankegang (Lakoff 2008a). Hvis man er præget af denne retorik, og opfattelsen af 'skat som en byrde' ikke erstattes af et klart alternativ, så vil man altså være langt mere tilbøjelig til at være enig med højrefløjen.

\section{Et venstreorienteret syn på beskatning}

Venstrefløjen har brug for en alternativ framing, der bygger på egne værdier. Et alternativ for venstreorienterede kunne være at benytte ord som 'skattesænkning' i stedet for 'skattelettelse', og 'fællesskabsinvestering' eller 'samfundsbidrag' i stedet for 'skat'. Med det første udtryk aktiverer man en mere neutral sagsdefinerende frame, mens man med de to andre aktiverer en klart venstreorienteret sagsdefinerende frame, hvor skat reframes til at udgøre et positivt bidrag til samfundet, og man dermed aktiverer et venstreorienteret samfundssyn. I denne frame appellerer man til idéen om, at vi alle kan være stolte af at bidrage til vores velfærdssamfund, som drager omsorg for os og giver os begrænset ulighed og store muligheder. I Norge har venstrefløjen meget tydeligt taget framing til sig som politisk værktøj og blandt andet omdøbt statskassen til 'fælleskassen', skattesystemet til 'den norske model' og skatteopkrævningen til 'spleiselag'. Fælles for disse frames er, at de aktiverer en langt mere positiv og fællesskabsorienteret forestilling om, hvad skat er. Den norske framing tager udgangspunkt i, at venstrefløjen rent faktisk mener, at det er både vigtigt og godt at betale skat. Begreber som f.eks. 'fællesskabsinvestering' lyder muligvis kunstige og uelegante. Men det skyldes i udgangspunktet blot, at vi er vant til at kalde fænomenet noget andet. En af de vigtigste ting ved strategisk framing er, at man skal være 
vedholdende; en ny overflade-frame skal gentages igen og igen, før den slår igennem, aktiverer de grundlæggende idéer, bliver taget op af andre og kan komme til at dominere debatten (Lakoff og Wehling, 2012).

\section{Krisen: Hvem bærer ansvaret?}

Et andet klart eksempel på dagsordensættende højrefløjsframing drejer sig om den nuværende økonomiske krise. Den er blevet reframet til en 'statsgældskrise', hvormed fokus flyttes fra problemerne med stigende 'finansialisering', deregulering af finansmarkederne og boligboble over på statsbudgetternes underskud. Størstedelen af den statsgæld, som flere og flere lande kæmper med, blev skabt for at redde banker og som følge af andre konsekvenser af finanskrisen, såsom øgede udgifter til arbejdsløse og færre skatteindtægter. Men i den højreorienterede sagsdefinerende frame bliver 'statsgæld' til et argument for, at staternes indretning ikke er bæredygtig på lang sigt, og at krisen skyldes velfærdsstatsligt overforbrug. Med overflade-framen 'statsgældskrise' som sagsdefinerende og problemdiagnosticerende udgangspunkt for borgernes opfattelse af krisens årsag har højrefløjen haft forholdsvis nemt ved også at dominere debatten omkring krisens løsningsmuligheder. Framingen tilbyder den helt simple løsning at sænke skatten og reducere velfærdsstaterne for hvis den offentlige sektor overforbruger, må den tøjles og formindskes. Det bliver det dominerende billede i alle europæiske lande, selvom mange lande ikke umiddelbart har noget gældsproblem. Men med den velvalgte reframing har højrefløjen haft held til at overbevise mange om, at europæernes dovenskab og de europæiske staters fråseri har forårsaget den nuværende økonomiske krise. Det skyldes blandt andet de grundlæggende moralske følelser, som vækkes i mange, ved snak om gæld. Gæld er noget dårligt, en negativ værdi, som derfor skal betales tilbage snarest muligt. Så når man (i dette tilfælde staterne) skylder penge væk, er det mest moralske at bide tænderne sammen og arbejde hårdere.

Det er sådanne frames, som venstrefløjen bør være meget opmærksom på og bør være i stand til at modsvare. Man bør undgå uden videre at acceptere den højreorienterede framing, sådan som det ellers har været tilfældet bl.a. med denne udtalelse fra Helle Thorning-Schmidt:

„Vi skal huske på, at der er to problemer. Der er et gældsproblem - det er vi godt i gang med at løse. Og så er der også et disciplinproblem ... Det handler simpelthen om, at de aftaler som eurolandene har lavet med hinanden, der har landene ikke været flinke nok til at overholde de aftaler." ${ }^{\text {"20 }}$

Her bekræfter Thorning, at der er tale om en 'statsgældskrise', hvormed hun gentager og bestyrker denne frame. I stedet burde hun have tilbudt en alternativ frame, hvilket vi vender tilbage til nedenfor.

\section{Kad krisen sammen med dens ophav}

Venstrefløjen har altså ikke formået at forklare krisen ud fra sine grundlæggende politiske idéer. Men hvorfor var ordet finanskrise ikke hensigtsmæssigt ud fra et venstreorienteret perspektiv? I dag vækker ordet stærke associationer, men tilbage i 2008 var det simpelthen for abstrakt. Der knyttede sig ingen konkrete billeder til denne overflade-frame, man så måske højst en mand i jakkesæt for sig. Framen udtrykker ikke i sig selv nogen direkte positiv eller negativ holdning til fænomenet og fungerer ikke handlingsanvisende, sådan som en god og effektiv sagsdefinerende frame gør det. En mere venstreorienteret, klar og værdiladet overflade-frame kunne være 'kasinokrisen'. Ordet er fængende, og brugen af det ville derfor sandsynligvis hurtigt kunne sprede sig. Samtidig giver ordet en klar vurdering af krisens ophav og giver et tydeligere billede af, hvem der i venstrefløjens optik er synderne: Finansfolkene, der har spillet hasard med hele verdensøkonomien. De moralske følelser, som denne frame vækker, placerer ansvaret for krisen der, hvor venstrefløjen mener den hører til - og fordømmer samtidig syndernes gerninger: Besøg på kasinoer og gambling er noget dårligt og amoralsk, men langt værre bliver det, hvis pengene, man gambler for, ikke er ens egne. De, der har gamblet og tabt, må udvise social ansvarlighed og forsøge at tilbagebetale deres gæld til samfundet.

Ved at benytte en stærk reframing placeres ansvaret for den økonomiske krise der, hvor venstrefløjen mener, at den hører hjemme. Ansvaret for finanskrisen kan kun blive placeret der, hvis de grundlæggende værdier udtrykkes gennem sproget og bliver fortalt konsekvent.

\section{Vejlegårds-sagen: Frihed for 'den lille mand'}

Vejlegårds-sagen er et bemærkelsesværdigt eksempel på en af højrefløjen veltilrettelagt og veludført framingstrategi. Sagen tog sin begyndelse i november 2011, da Restaurant Vejlegårdens nye forpagter, Amin Skov, brød den eksisterende overenskomst med fagforeningen $3 \mathrm{~F}$ og i stedet indgik aftale med den gule fagforening Krifa. De ansatte på 3F's overenskomst fik at vide, at de måtte acceptere den nye overenskomst med Krifa, hvis de ville beholde deres job. Dette fik 3F i Vejle til at igangsætte en blokade og senere en sympatikonflikt mod restauranten. 3F fører massevis af lignende sager hvert år uden den store medieomtale, men netop denne sag rundede i nogle uger i løbet af juli måned 2012 over 2.000 hits på Infomedia. At det var agurketid, er ikke den eneste forklaring. En anden væsentlig årsag var nemlig, at højreorienterede meningsdannere gjorde sagen principiel, hvilket bl.a. fremgår af figur 3 . 
Figur 3. Vejlegårdssagen i tal

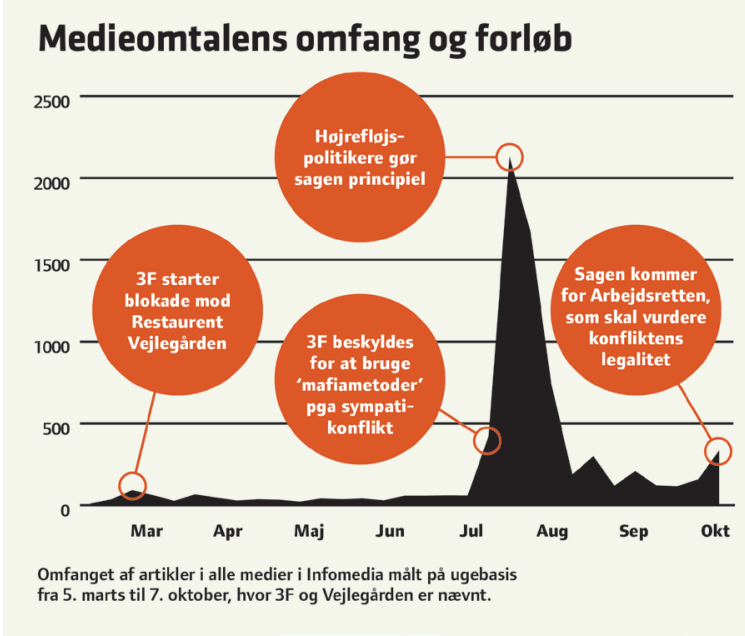

Figuren, med tilladelse genoptrykt fra en artikel af Anders Dybdal i tidsskriftet VISION fra 7. oktober 2011, giver et overblik over Vejlegård-sagens forløb og talspersoner.

*Omfanget af artikler i alle medier i Infomedia er målt på ugebasis fra 5. marts til 7. oktober, hvor 3F og Vejlegården er nævnt.

${ }^{* *}$ Andelen af artikler i alle medier i Infomedia fra 1. juli til 1. oktober 2012, hvor 3F, Vejlegården og navnet på en debattør er nævnt. Debattørens navn optræder inden for 5 ord af enten mener/siger/udtaler.

Først og fremmest blev sagen framet som en frihedskamp, hvilket blev gentaget som et mantra af højreorienterede politikere såsom Inger Støjberg $(\mathrm{V})$ og Simon Emil Ammitzbøl (LA), men også af Amin Skov selv: „Man skal finde sig i meget, hvis man vælger en anden vej, end flertallet er tvunget til ... Hvor er mit demokratiske valg til at vælge Krifa fremfor $3 \mathrm{~F}$ ?", udtalte han f.eks. i et interview til BT. ${ }^{5}$ Frihed er naturligvis i sit udgangspunkt et plusord for alle, men betyder noget forskelligt for venstreorienterede og højreorienterede. Begrebet 'frihed' er, hvad der kaldes en flydende betegner; et centralt ord, hvis betydning der kæmpes om at fastlægge (Laclau, 2005). Abstrakte begreber som 'frihed' må altså ledsages af en klart udtrykt fortolkning, hvis de skal være meningsfulde og have appel. I dette tilfælde satte højrefløjen sig tungt på definitionen af 'frihed', hvorfor det umiddelbart virkede helt berettiget, at Amin Skov skulle have 'frit valg'. Igen handler det om dybtliggende erfaringer og værdier, hvor de fleste vil være pro frihed, når modsætningen er tvang. Det højreorienterede frihedsbegreb, og dermed også det højreorienterede verdenssyn, forstærkes altså i det kognitivt ubevidste med denne frame. Framen indeholder ikke en eksplicitering af, at det frie valg i denne sammenhæng er forbeholdt arbejdsgiveren. Arbejdstagernes frihed til at organisere sig, til indflydelse på egne løn- og arbejdsvilkår, negligeres.

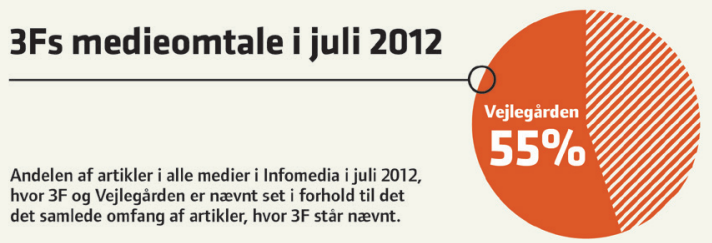

\section{Mest citerede personer i Vejlegårdssagen}

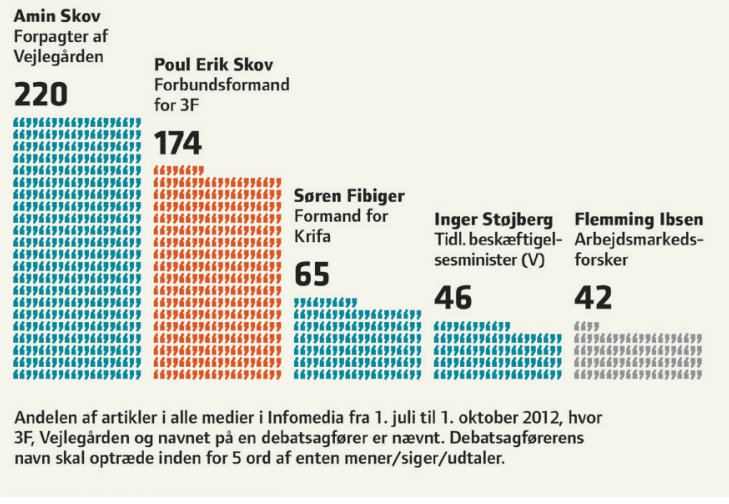

\section{Hvem kan vare imod retfardighed og lovlydighed?}

Vejlegård-sagen er en regulær guldgrube af højreorienterede overflade-frames, hvorfor vi kan tage et andet godt eksempel, her udtrykt af Liberal Alliances formand Anders Samuelsen:

„Det, der er mafiaagtigt ved det, det er jo, at mafiaen er kendt for, at man går ind og lægger et pres på en lille selvstandig erhvervsdrivende - og siger, hvis du ikke gør, lige som vi vil have du skal gøre, så lukker vi din forretning. Det er faktisk det, som 3F gør. ${ }^{“ 6}$

Restaurantejeren Amin Skov bliver med denne framing til et symbol på 'den lille mands kamp mod onde magter' - som David mod Goliat. Og 3F's ønske om at organisere lønmodtagerne på Vejlegården bliver sammenlignet med mafiaens afpresning af sagesløse og retskafne borgere. Denne frame indeholder flere værdimæssige undertoner, som klart kommer højrefløjen til gode: Der appelleres til borgernes retfærdighedsfølelse ved at antyde, at den store, magtfulde fagforening angriber den lille mand. Dermed aktiverer framen den bredt accepterede morale, at man 'ikke skal slå på nogen, der er mindre end en selv'. 3F's ærinde fremstilles altså som uædelt og, i kraft af mafia-metaforen, som på kant med loven. Framen gør fagforeningen til en "mastodont ${ }^{\text {" }}$ af et egenrådigt og aggressivt subjekt, og aktiverer dermed slet ikke fagforeningens grundlæggende værdier om fæl- 
lesskab og lige muligheder. Framen negligerer, at fagforeningen ikke er en egenrådig aktør, men repræsenterer et fællesskab. Den veltilrettelagte højreorienterede framing af Vejlegård-sagen betød, at Amin Skov blev helten, og 3F skurken i den brede offentlighed. Sommerens debat viste således klart, at fagbevægelsen ikke har været god nok til tydeligt at kommunikere sine grundlæggende værdier, idéer og formål.

\section{Konfliktretten truet}

Effekten af framingen blev, at man på højrefløjen og $\mathrm{i}$ dele af befolkningen begyndte at tale for en afskaffelse af konfliktretten over for virksomheder med overenskomst. Venstre og Dansk Folkeparti fremsatte således et beslutningsforslag, ${ }^{8}$ der skulle begrænse konfliktretten og dermed potentielt kunne komme til at underminere hele den danske aftalemodel på arbejdsmarkedet. På trods af, at dette efter al sandsynlighed ville medføre ringere arbejdsforhold for majoriteten af de danske lønmodtagere, mødte forslaget en vis folkelig opbakning. Framingen med 'den lille mand' over for den store, magtfulde og mere ansigtsløse institution betød, at folk identificerede sig med, og derfor sympatiserede med, Amin Skov. Samme framingstrategi blev brugt af Kristelig Arbejdsgiverforenings direktør Karsten Høgild: „For restauranten handler det her om liv eller død, mens $3 \mathrm{~F}$ kæmper for et par medlemskaber. Det er en ulige kamp." Igen bliver sagen gjort til et spørgsmål om institutionen 3F's moralske karakter og dennes økonomi.

\section{Forbruger-frame var et darligt modsvar}

3F's eget modsvar på den stærke, højreorienterede framing var et forsøg på at vinde opbakning gennem tal og fakta: „Den overenskomst, de kristelige har, mener vi er 10-15 procent dårligere på alle punkter", udtalte gruppeformanden for restaurationsområdet i 3F i Vejle, Henning Troelsen, således til BT. ${ }^{10}$ Men som nævnt ovenfor er en appel til det rationelle menneske om 'den objektive sandhed' ikke særlig effektiv kommunikation. $3 \mathrm{~F}$ og venstreføjen leverede ikke en slagkraftig og tydeligt værdiladet reframing, som kunne udfordre den højreorienterede framingstrategi. I stedet vidner Henning Troelsens udtalelse om, at sagen blev defineret som et spørgsmål om økonomi for den enkelte lønmodtager - om, hvor den enkelte får den bedste 'deal'. Hermed aktiverer Troelsen dybde-frames, der knytter an til højreorienterede værdier såsom individualisme, konkurrence og forbrugermentalitet. De færreste fagforeningsfolk ville nok betegne deres medlemmer som kunder. Ikke desto mindre er det præcis det, som denne framing gør dem til. Fagforeningen bliver her til en butik, som efter sigende skulle have bedre varer på hylderne end konkurrenten. Fagbevægelsens grundlæggende værdier om fællesskab og solidaritet bliver slet ikke aktiveret. Fortællingen om, at 3F er et fællesskab af arbejdstagere, der ønsker at stå stærkere sammen mod løntrykkeri, er stort set fraværende. I stedet for at frame debatten strategisk og dermed aktivere mere venstreorienterede dybde-frames blandt den danske befolknings mange 'biconceptuals', skød 3F de værdimæssigt sammensatte fra sig. Argumentet om, at konflikten skulle være velberettiget fordi 3F's tilbud er 10-15 pct. bedre end Krifas, var derfor ikke stærkt nok til at overbevise den brede offentlighed. 3F gik altså ind i diskussionen om Vejlegårds-sagen med brug af højreorienterede værdier og præmisser, hvilket ikke kom dem til gode.

Figur 4. Oversigt over højreføøjens framing og den reframing, der burde have været venstrefløjens modsvar.

\begin{tabular}{|c|c|}
\hline \multicolumn{2}{|c|}{ Værdier og principper - dybde-frames } \\
\hline Amin Skov og højrefløjen & 3F og venstrefløjen \\
\hline $\begin{array}{l}\text { Individualisme, egennyttemaksimering, fællesskabet er undertrykkende, frihed } \\
\text { = fravær af tvang, selvhjulpenhed, er man afhængig af andre, er man svag }\end{array}$ & $\begin{array}{l}\text { Social ansvarlighed, empati, gensidig respekt, æællesskabet giver os styrke, } \\
\text { frihed er friheden til faglig organisering og lige muligheder for alle }\end{array}$ \\
\hline \multicolumn{2}{|c|}{ Konfliktens kerne - sagsdefinerende frames } \\
\hline $\begin{array}{l}\text { Den lille, selvstændige erhvervsdrivenes frihed til selv at bestemme over sin } \\
\text { virksomhed og vælge overenskomst } \\
\text { Arbejdsgivers rettigheder krænkes (offer) af } 3 F \text { (skurk) }\end{array}$ & $\begin{array}{l}\text { Arbejdstagers frihed til at organisere sig for bedst mulige arbejdsvilkår } \\
\text { Arbejdstagers rettigheder krænkes (offer) af arbejdsgiver (skurk) }\end{array}$ \\
\hline \multicolumn{2}{|c|}{ Retorik - overflade-frames } \\
\hline $\begin{array}{l}\text { 3F er en ansigtsløs mastodont, der kanøfler den lille mand } \\
\text { 3F bruger mafia-metoder } \\
\text { 3F kæmper bare for et par medlemskaber } \\
\text { Den danske model er forældet }\end{array}$ & $\begin{array}{l}\text { Fagforeningen er et fællesskab af mennesker } \\
\text { 3F kæmper for fællesskabets bedste og beskytter mod uorganiserede uden- } \\
\text { landske løntrykkere, gule skruebrækkere og urimelige arbejdsgivere } \\
\text { Amin Skov udviser ikke respekt for sine ansattes frie valg til at organisere sig } \\
\text { Den danske aftalemodel er dynamisk og sikrer fleksibilitet og velstand }\end{array}$ \\
\hline \multicolumn{2}{|r|}{ Politiske tiltag } \\
\hline Afskaffelse af konfliktretten over for virksomheder med overenskomst & $\begin{array}{l}\text { Bevarelse af konfliktretten over for virksomheder med overenskomst er es- } \\
\text { sentiel for vores samfund }\end{array}$ \\
\hline
\end{tabular}


Historien ville muligvis have været en anden, hvis 3F havde haft en stærk framingstrategi i stil med den, der fremgår af figur 4.

\section{Hvordan framer vi fællesskabet?}

Vejlegårds-sagen er, som før nævnt, symptomatisk for venstrefløjens manglende evner udi strategisk framing. Venstrefløjens grundlæggende værdier burde gennemsyre en bevidst og konsekvent framing, der sætter fokus på fællesskabet. For hvem har ikke gavn af fællesskabet? Enhver privat virksomhed bruger og lukrerer på fællesskabet. ${ }^{11}$ Virksomhederne benytter arbejdskraft, som er uddannet ved hjælp af fællesskabets midler, og de benytter elektricitet, som leveres til dem af offentligheden. Det kan simpelthen ikke lade sig gøre at tjene en eneste krone eller have succes i den private sektor overhovedet, hvis ikke vi havde vores fælles offentlighed. Derfor har virksomheder selvfølgelig et ansvar for at bidrage til samfundet og på den måde opveje for det, som offentligheden giver dem. Hvorfor italesætter venstrefløjen ikke dette forhold skarpere?

Hvis venstrefløjen igen skal have held til at sætte den politiske dagsorden, må den sørge for at kommunikere sit syn på virkeligheden klart og tydeligt. For at kunne de, må venstrefløjens sprog afspejle dens værdier, og et oplagt sted at starte ville være at forsvare den danske velfærdsmodel. Den sproglige markedsgørelse af samfundet kan bekæmpes med en reframing, der lægger vægt på borgernes indbyrdes forbundenhed, på omsorg, empati og fællesskab. Frames, der afspejler denne venstreorienterede samfundsopfattelse inkluderer 'ældrepleje' og 'uddannelsesstøtte', men en række af velfærdsopgaverne kan ligeledes reframes, så de direkte aktiverer grundlæggende venstreorienterede idéer. Det kunne være med ord som 'borgerhjælp' i stedet for borgerservice, 'sundhedspleje' i stedet for sygesikring og 'ældrestøtte' i stedet for folkepension. En sådan reframing etablerer et udgangspunkt, hvor folkestyrets vigtigste opgave er at beskytte, støtte og styrke alle borgere og sikre alle lige muligheder. Dette lader sig gøre gennem en fælles offentlighed, som er opbygget i fællesskab og ejet i fællesskab.

\section{Venstrefløjens partier kan tage til genmæle}

Der er intet odiøst eller manipulerende ved framing. Det er intet nyt $\mathrm{i}$, at denne proces har ekstremt stor indfly- delse på de politiske diskussioner og de politiske værdier. Det er en fast bestanddel af moderne politik, som eksisterer, uanset om vi er opmærksomme på den eller ej. Derfor er spørgsmålet også kun, om man vil frames af andre, og dermed også af andres værdier, eller om man selv vil gå aktivt ind i kampen. Ved at acceptere højrefløjens frames har centrum-venstre-partierne ikke vundet vælgerne tilbage, men i stedet medvirket til at gøre dem mere højreorienterede ved at aktivere deres højreorienterede erfarings- og forestillingsgrundlag. Vil venstrefløjen fremme venstreorienteret politik, må de i stedet for at forsøge at ligne de andre partier mest muligt, definere klare alternativer gennem strategisk framing. Den helt grundlæggende politiske udfordring på venstrefløjen kan altså opsummeres således:

- Man er nødt til at forstå, at sproget ikke er neutralt

- Man er nødt til at forstå, at sproget påvirker vores virkelighedsopfattelse

- Man er nødt til at skabe et politisk sprog ud fra egne værdier

- Og det er ikke godt nok at negere sin modstanders udsagn

Det må derfor betegnes som venstrefløjens helt store udfordring at få skabt et sammenhængende, dagsordensættende og værdimæssigt funderet sprog. Fortsætter man med at bruge højrefløjens sprog, bidrager man kun til at aktivere de dele af borgernes hjerner, som man er uenig med - og det er ganske enkelt selvundergravende virksomhed. Vil venstrefløjen vinde, skal den have aktiveret de dele af borgernes hjerner, der er enige med den - ikke de dele, der er uenige.

Konklusionen er således på ingen måde, at højrefløjen bruger ufine og manipulerende metoder, mens venstrefløjen er god og ægte. Tværtimod er det højrefløjen, der har fat i den lange ende, som har tilegnet sig en mere præcis opfattelse af rationalitet og som dermed har kunnet sætte sig på den politiske dagsorden. De har forstået sammenhængen mellem sprog og værdier som grundlaget for den framing, der er en grundlæggende præmis i enhver politisk debat. Framing er ikke noget, man kan vælge eller fravælge at benytte sig af. Du kan enten aktivt frame selv, eller du kan blive framet. Lige nu er det det sidste, der er tilfældet for venstrefløjen. 


\section{Litteratur}

Berlin, Isajah. 2005. Den ideale straben og andre essays. Kobenhavn: Gyldendal.

Black, E. 1970,"The Second Persona", The Quarterly Journal of Speech, vol. 4, no. 2, pp. 109-119.

Cevea, 2012, Galdskrisen er skabt $i$ den private sektor, Cevea, København, kan lokaliseres her: http://www.cevea.dk/files/materialer/ analyser/notat_statsgaeld_og_privat_gaeld_0.pdf

Edelman, M. 1971, Politics as Symbolic Action, Markham Publishing Company, Chicago.

Gazzaniga, M. 2011, Who's in Charge?: Free Will and the Science of the Brain, Ecco, New York.

Gazzaniga, M, 1988, Mind Matters: How Mind and Brain Interact to Create our Conscious Lives, Houghton Mifflin, Boston.

Gonzalez-Castillo, J. et al 2012, „Whole-brain, time-locked activation with simple tasks revealed using massive averaging and model-free analysis", PNAS, vol. 109, no. 14 http://www.pnas.org/content/ early/2012/03/14/1121049109.full.pdf+html

Iyengar, S. 1991. Is Anyone Responsible?, Chicago, The University of Chicago Press.

Jespersen, Per Michael, 2010, „De røde har glemt følelserne“, http:// politiken.dk/debat/ECE873494/de-roede-har-glemt-foelelserne/

Johnson, M. og Lakoff, G. 2003 [1980], Metaphors We Live By, University of Chicago Press, Chicago.

Laclau, Ernesto. 2005. On Populist Reason. London: Verso

Lakoff, G. 2008a, The Political Mind: why you can't understand 21st-century politics with an 18th-century brain, Penguin Group, New York.

Lakoff, G. 2006, Thinking Points: Communicating Our American Values and Vision: a Progressive's handbook, Farrar Straus \& Giroux.

Lakoff, G. 2004, Don't think of an elephant!, Chelsea Green Publishing Company, Canada.

Lakoff, G. 2008b, The Mind and the Obama Magic. Lokaliseret 8. januar 2013 på http://www.huffingtonpost.com/george-lakoff/the-mindand-the-obama-ma_b_111105.html

Lakoff, G. og Wehling, E. 2012, The little blue book: the essential guide to thinking and talking democratic, Free Press.

Luntz, F. 2006, The Republican Playbook, originalversionen er ikke offentligt tilgængelig, men er lokaliseret 11. januar på: http://www. yuricareport.com/BushSecondTerm/Luntz.pdf

McGann,James og Sabatini, Robert, 2011 , Global Think Tanks - Policy Networks and Governance, Routledge

Mouffe, Chantal. 2005. On the Political. New York: Routledge.

Nelson, Thomas E. \& Zoe M. Oxley \& Rosalee A. Clawson. 1997, Toward a Psychology of Framing Effects, Political Behaviour, vol. 19, no. 3 .

O'Neill, Timothy P. 2009. Sotomayor can't escape an overworked word. Chicago Daily Law Bulletin, vol. 155, issue 178. Lokaliseret d. 23.januar på

http://www.jmls.edu/directory/profiles/oneill-timothy/pdfs/column\%20September\%202009.pdf
Perelman, C. og Olbrechts-Tyteca, L. 1969, The New Rhetoric. A Treatise on Argumentation, Trans. J. Wilkinson og P. Weaver. University of Notre Dame, Indiana.

Plehwe, Dieter (red) et al, 2006, Neoliberal Hegemony - A Global Critique, Routledge

Reinhart, C. og Rogoff, K. 2011, This time is different: Eight centuries of financial folly, Princeton University Press.

Rock, A. 2005, The Mind at Night: The New Science Of How And Why We Dream, Basic Books.

Vatz, R 1973, „The Myth of the Rhetorical Situation“, Philosophy \& Rhetoric, vol. 6, no. 3, pp. 154-161.

Westen, D. 2007, The political brain: the role of emotion in deciding the fate of the nation, Public Affairs, USA.

Wunderlich, K. 2009, „Neural computations underlying action-based decision making in the human brain", PNAS, vol. 106 no. 40 http:// www.pnas.org/content/106/40/17199.full.pdf+html

\section{Noter}

1. En diskussion af samme emne findes også i: Lakoff, George (2008). The Political Mind: why you can't understand 21st-century politics with an 18th-century brain. New York: Penguin Group (47-51).

2. Det danske partisystem anskues ofte som værende orienteret på to forskellige akser: en klassisk-økonomisk højre/venstreorientering over for en værdipolitisk højre/venstreorientering. Dette kan ses som en modsætning i forhold til det amerikanske topartisystem, hvor de to akser mere eller mindre er tvunget sammen. Men da de allerfleste vælgere er værdimæssigt sammensatte, kan man som parti således fint frame ud fra eksempelvis højreorienterede økonomiske idéer og venstreorienterede værdipolitiske idéer - framingen definerer jo netop årsager, problemer og løsningsmuligheder fra sag til sag. Man kan altså godt gå efter at aktivere og forme opfattelser, der umiddelbart øger den forestillingsmæssige dobbelthed eller polaritet hos modtageren.

3. „Løkke vil totalfrede erhvervsliv frem til valg“, Politiken, 17. februar 2013.

4. Tv-debat med Helle Thorning-Schmidt, DR 1, 3. januar 2012.

5. I Amin Skov. i BT, 5. juni 2012

6. Anders Samuelsen i debat, TV2, 2. august 2012.

7. Inger Støjberg, interviewet på TV2, 1. august 2012.

8. Beslutningsforslaget fik megen omtale, men se f.eks. http://m.business.dk/touch/article.pml;jsessionid=534950B4A0892C902A4137 B854A88752.uw-portal4?guid $=21538646$

9. Karsten Høgilds tale til moddemonstration refereret i Vejle Amts Folkeblad, 29. juni 2012.

10. Henning Troelsen, gruppeformand for Hotel og Restauration under 3F i Vejle, citeret i BT's artikel „Hårdt mod hårdt i faglig strid“ d. 29. juni 2012.

11. En diskussion af samme emne findes også i: Lakoff, George (2008). The Political Mind: why you can't understand 21st-century politics with an 18th-century brain. New York: Penguin Group (47-51). 